\title{
From Epistemological Pedagogical Access to Student Success: New Framework for
}

\section{Studying Access to Higher Education}

\author{
* Ms. Irfana Omar, PhD Scholar (Corresponding Author) \\ ** Dr. Seema Arif, Associate Professor
}

\begin{abstract}
Research related to access to higher education is often criticized for lacking a strong theoretical ground, arguing it is limited to seek information regarding the quality of infrastructure or teaching and learning. This study, however, seeks to draw a model for meaningful access to higher education regarding epistemic quality. For this purpose, the relationship between factors influencing pedagogical access (Teacher Pedagogic Quality, Teaching Learning Environment, and Teacherstudent Relationship) and factors leading to student success (student satisfaction and student engagement) is assessed. The researchers assume that meaningful and purposeful access is created for a diverse population entering higher education only by providing 'epistemological-pedagogical access, ' ensuring student success. The study was quantitative, and correlational research design was used following the positivist paradigm. The researcher used a multi-stage sampling technique, to approach the target sample of 400 students studying in universities of Lahore (one public and one private). a close-ended questionnaire was self-constructed for the data collection, and advanced statistical techniques Pearson Correlations, and multiple regressions were applied using SPSS. The study concludes a model of epistemological-pedagogical access leading to success for the university students of Pakistan. Furthermore, this pilot study results also share the predictive value of pedagogical access to ensure student success.
\end{abstract}

Keywords: Epistemological - Pedagogical Access, Student Success, Student - Teacher

\section{Introduction}

Relationships, Teacher Pedagogic Quality, Teaching, and Learning Environment

If 'access' to higher education is 'gaining' of a place to study in higher education institutes, then 'epistemological access' is 'meaningful access' to available resources: infrastructure, teaching services, and learning environment at higher education institutions to transform educational experiences into purposeful opportunities in the broader society (Morrow, 2009; Clegg, 2011; Omar \& Chaudhary, 2019). The research on epistemological access has mushroomed since Morrow's (1994) first study checking the South African education system for the purpose. Lotz-Sisitka (2009) proclaimed that the epistemological muddle is not merely a challenge for South Africa but also the modern world for purposeful education. The prevailing 'culture of entitlement' mixed the entry (enrolment) in educational institutes (Alexander, 2008) with qualification (post-enrollment experience) a pertinent definition provided by Samoff (2001). This confusion has further blurred the picture between physical access and epistemological access, compartmentalizing quantity, and quality in two separate baskets (Morrow, 2007; Govinda and Bandyopadhyay, 2011). Whereas Motala \& Carel (2019) claimed that access to higher education should better be understood; not as providing a place to get a degree, but from the perspective of meaningful learning for real-life achievements. Such education and learning cannot be automatically injected in students who pay their fees and attend the classes by providing them what to learn; instead, it would answer how to learn to question to ensure quality teaching and learning practices (Pendlebury, 2009). So, a distinction between 'knowing that' and 'knowing how' shall be made for purposeful learning because the practical ability is more important than theoretical knowledge (Ryle, 1945; Fantl, 2008; Winch, 2012).

\footnotetext{
* University of Management \& Technology Lahore, Pakistan Email: irfana.omer1@gmail.com

** University of Management \& Technology Lahore, Pakistan Email: seema.arif@umt.edu.pk
} 
Teaching is a complex skill occurring in an ill-structured environment. Until recently, pedagogy focused on mere content to be covered by the teacher; now, the focus has shifted to the teachers' pedagogical content knowledge for the successful transformation of students. Pedagogical knowledge refers to a deep understanding of the techniques and methods involved in the teachinglearning process to enable the teachers to apply social, cognitive, and developmental theories of learning for knowledge construction and skill acquisition of their learners (Mishra \& Koehler, 2006). It is significant to learn how the subject matter or content is transformed, making it more accessible to learners. The question of how specific content is organized and represented for instruction is valued as an epistemological underpinning.

Besides, Alexander (2015) takes pedagogy as a missing ingredient in discussions on educational quality. Mere fund of knowledge approach is not enough; instead, pedagogical modality to complement the knowledge is necessary for purposeful learning (Fattar, 2012). The evidence from students, teachers, policymakers, and scholars offers a new perspective as to how pedagogy needs to be remodeled.

\section{Literature Review}

In this paper, researchers argued that the investigation on pedagogical access to higher education needs a comprehensive framework, such as opting for the epistemological stance. To explore epistemological-pedagogical access to Higher education, researchers followed three relevant constructs: Teacher Pedagogical Quality (TPQ), Teaching Learning Environment (TLE), and Teacher-Student Relationship (TSR).

\section{Teacher Pedagogical Quality (TPQ)}

To ensure successful learning of students, the researcher conceptualized two principles of TPQ: i) Authentic pedagogy (Newmann et al., 1996), which takes pedagogy as the combination of assessment and daily teaching practices of the instructors for meaningful learning and cognitive development of students, and ii)Teacher Pedagogical Content Knowledge (Shulman, 1987) which refers to the blending of content and pedagogy as an attempt to enable the teachers to organize and present the content in an adaptive way to meet the diverse needs of learners for a successful transfer of knowledge. It is valued as an epistemological stance that purposefully merges both content and pedagogy to ensure learning.

Unfortunately, most pedagogues use a transmission approach to instruction expecting their learners to memorize and regurgitate foreordained information in the provided books, which makes the students stray without any conceptual clarity. Such practice of teachers hardly leaves any assurance that students are skilled enough to transfer the learned concepts, theories, and perspectives to real-life situations (Gürgil, 2018). Contrarily, pedagogues using the constructivist approach believe lesser in replicating information than involving the students in interpreting the text, analyzing theories, and evaluating various perspectives to generate new ideas (Biggs, 2014; Sloan \& Bowe, 2014). These teachers follow a student-centered approach and demand the active participation of the learners offering cooperative group-activity projects. The questions arise: does this 'active participation' result in 'active learning' or not; does this pedagogical effort provides access to real intellectual achievement or not.

Research evidence (Joyce et al., 2018) supports the fact that active learning can be pursued through the active participation of students. However, at certain times even active participants follow an illusory path - where only participation in an activity is taken as the criteria for learningresulting in the production of shallow and surface-level intellectual work. This low standard of intellectual activity sets the criteria for conventional academic achievement involving retrieval and imitation of the knowledge transmitted in contrast to the authentic academic achievement, which has utilitarian, aesthetic, and personal value apart from certifying success in the form of grades. To meet the standards of intellectual quality for the valued end, authentic pedagogy, i-e faithful practice to meet the high intellectual standards, deserves the practitioners' attention (Skourdoumbis, 2014).

Newmann et al. (1996) enunciated three criteria for authentic intellectual work, that is, construction of knowledge, disciplined inquiry, and value beyond school. Knowledge construction refers to using the interpretation of information, deductive reasoning, and evaluation of ideas instead of merely replicating the previous idea. Disciplined inquiry refers to the in-depth mastery of limited concepts instead of surface-level acquaintance with many in hand. Value beyond school refers to the 
production of knowledge with personal, utilitarian, and aesthetic value beyond mere documentation of a student's competency. Advocates of Authentic pedagogy (Cydis, 2015) assert that the mere relevance of an original work to real-life problems does not suffice the purpose; instead, it demands exhaustive in-depth thinking whereby teaching primary knowledge skills to promote high-quality intellectual work are a precedent. A review of empirical research (Muller, 2014) indicates that the authenticity of work is more exciting and engaging to students than conventional drills of non-events. Bagnall and Hodge (2017) also spotlight existing diversities and demands to rethink the philosophy on instruction and reform the pedagogical model that offers integration of authentic, performancebased, and competence-based approaches through the development of cognitive abilities while offering complex substantive tasks to the students.

The more the students learn, the more value they give to their learning, and the more likely they reflect on the shortcomings of their learning experience, which in turn helps to be self-directed in their learning process. Newman et al. (1996) report many cases where instruction and achievement met the high standards of quality, and the instructors vocalized that challenge for authentic instruction is to meet the demands of minorities. Many instructors narrated that they found it hard to meet the set standards and faced many obstructions. The good thing is that though it is challenging, it is possible to transform the educational institutes and meet the academic expectations articulated by authentic instruction advocates.

\section{Teaching Learning Environment (TLE)}

Authentic learning requires solving significant problems related to real-world contexts. Teachers need to differentiate between contextualized and de-contextualized knowledge to better connect the content for teaching at various levels with the best pedagogic techniques for effective teaching and learning (Lotz-Sisitka, 2009; Magolda, 2014). It also demands re-contextualization (Bernstein, 2013) and adopting an open-ended notion of epistemological access by using an inter-disciplinary and transdisciplinary approach to find solutions for the complex contexts of the postmodern world (LotzSisitka, 2009). The culturally responsive framework also spotlights contextualization of knowledge to everyday lives, but the question arises 'whose' everyday context because diversity - cultural, ethnic, class, race - among students is a real challenge. Moll \& González (2004) extends the argument by a responsiveness framework: Curriculum responsiveness, economic responsiveness, situational responsiveness, disciplinary responsiveness, and learning responsiveness, and argues that purposeful learning occurs if the support system of the institutions is robust.

\section{Teacher-Student Relationship (TSR)}

The 'need to belong' affects interpersonal attachments, and the quality of relationships has a marked influence on human beings in general and in educational contexts (Bergin \& Bergin, 2009; Leary \& Baumeister, 2017). It is hard to gainsay the evidence (Roorda et al., 2011; Bernstein-Yamashiro \& Noam, 2013; Hagenauer et al., 2013) regarding the importance of the teacher-student relationship (TSR). Although this relationship is more highlighted in research at the school level, teacher-student relationship (TSR) cannot be divorced from pedagogical efforts in the higher education context as well (Hagenauer \& Volet, 2014a; Aldrup et al., 2018; Pennings et al., 2018). Researchers pointed out that teacher-student relationship (TSR) is a precondition of excellence in the teaching-learning process at university (Hagenauer \& Volet, 2014b; Roorda et al., 2017), so it is a relevant construct to define pedagogical efforts of teachers.

To explore TSR in higher education, the researchers used the conceptual framework suggested by Hagenauer and Volet (2014a); they have highlighted the multi-dimensional nature of TSR in higher education. They (Hagenauer and Volet) identified two critical aspects of the construct, 1) affective dimension, incorporating interpersonal connection that forms the basis for emotional connection and secure relationship between teacher and student; 2) support dimension focusing on the professional support provided to the students by teachers through TSR. In this study, 'affective TSR dimension' comprise three sub-components, 1) closeness (Bergin \& Bergine, 2009) taken in terms of attachment dyad based on attachment theory; it means that teachers are not only caregivers but also care-seekers (Riley, 2009, 2010). 2) Interpersonal adaptation in teacher-student interaction, referring to teacher-students' interpersonal actions and reactions in daily classroom interactions (Bozalek et al., 2014; Ramseyer \& Tschacher, 2016). 3) Nonverbal immediacy, which considers body posture, facial 
expressions, eye contact, and tone of voice as rapport building nonverbal behaviors (Gilbreath \& Eastman, 2017).

The support dimension is taken in terms of approachability, which means that approachable teachers exhibit caring behavior that enhances connectedness and belongingness to the campus resulting in better learning experiences (Snijders et al., 2020; Devlin \& O'Shea, 2012). Quality of TSR affects both teachers and students, resulting in teachers' job satisfaction (Hagenauer et al., 2015), as well as student commitment (Kim, 2017), increased effort (Lundberg \& Schreiner, 2004; Spilt et al., 2011), engagement (Zepke \& Leach, 2010), motivation (Zepke \& Leach, 2010), achievement (Roorda et al., 2011; Asikainen et al., 2018), course satisfaction (Calvo et al., 2010), and academic success (Karpouza \& Emvalotis, 2019).

There shall be informed partnerships between teachers and students for pedagogic change. Haseloff (2007) records a case study where students reported that though they were taken as active agents with their teachers to share a strategy for change in their learning, their role was kept as 'peripheral.' Most of the time, both teachers and students followed their individualized practical theories about teaching and learning, and it lacked shared collective codes that blocked pedagogic change. Moreover, all authority on pedagogic change was given to teachers only, and students' opinions were not valued. They were more taken as 'encumbrances' rather than 'allies' for pedagogic change. The learning model's dimensions confirm that the informed involvement of students in the pedagogic change process would result in better results.

Fig 1.

The Conceptual Framework of the Study

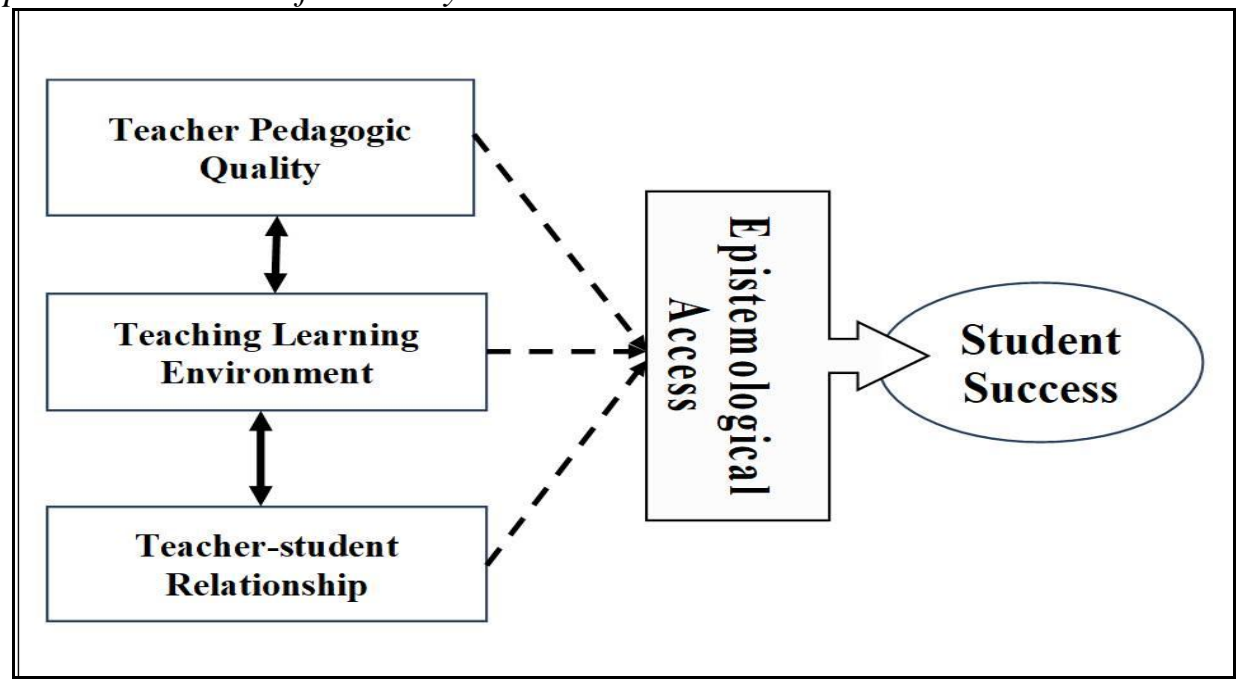

\section{Statement of the Problem}

The researchers assume that meaningful and purposeful access is created for a diverse population entering higher education only by providing 'epistemological-pedagogical access' to ensure student success. The study proposed a conceptual framework for purposeful access to higher education for determining the interactive effect of factors (Teacher Pedagogic Quality, Teaching Learning Environment, and Teacher-student Relationship) upon factors leading to student success derived from extensive literature review.

\section{Research Questions}

1. What is the interactive effect of factors influencing pedagogical access upon factors leading to student success?

2. Which are the dominant factors determining epistemological-pedagogical access to students at universities in Lahore?

\section{Methodology}

Quantitative research is well-adapted to establishing relationships between variables. It usually has a fixed design approach; moreover, surveys rely on the descriptive study of the phenomena using numerical means, instead of its outcomes. Researchers have used this approach to observe existing phenomena to fit a model in the local context (Cresswell, 2005). A correlational research design was opted to explore the relationship between two or more variables and determine which variables are 
interacting and what type of interaction is occurring among variables. Statistical control is used to find accurate estimates regarding the degree of relationships among variables (Becker et al., 2016), and the relationship found also provides the basis to predict an outcome (Cresswell \& Creswell, 2017).

A multi-stage sampling technique was opted to approach the target sample. Two universities (one public and one private) constitute the sample of study selected conveniently. Through criterion sampling, two faculties, Information and Technology and Business School, with a criterion of being old, established, and offering professional education, were selected for each university study. The student sample comprised of 100 under-graduate students of $5^{\text {th }}$ and $6^{\text {th }}$ semesters were selected as a cluster from each faculty, suiting the purpose of study, i.e., to examine students' perceptions and experiences regarding epistemological-pedagogical access to higher education and its effect upon student success, a self-constructed questionnaire comprising closed-ended items were used to extract opinions of respondents. The researcher rendered the close-ended questionnaire useful because "the results of closed-ended questionnaires helped the researcher in identifying a general pattern of participants' reactions to treatment or program" (Yilmaz, 2013, p.214). The questionnaire was peerreviewed for face validity, and expert reviewed for content validity. The items thus generated were pilot tested with 50 undergraduate students; the calculated reliability was .782 . The final questionnaire comprised of 37 items constructed on a 5-point Likert Scale. See Appendix A for further details.

\section{Results}

This section begins with a description of demographic characteristics; it carries on measuring the relationship between the factors of the study and concludes by assessing predictors of change independent variable.

Table 1.

Demography

\begin{tabular}{|c|c|c|}
\hline Gender & $\mathbf{F}$ & $\%$ \\
\hline Male & 80 & 40.0 \\
\hline Females & 120 & 60.0 \\
\hline Total & 200 & 100.0 \\
\hline \multicolumn{3}{|c|}{ Universities } \\
\hline UCP & 120 & 60.0 \\
\hline LCWU & 80 & 40.0 \\
\hline Total & 430 & 100.0 \\
\hline \multicolumn{3}{|l|}{ Age } \\
\hline 20.00 & 140 & 71.0 \\
\hline 21.00 & 52 & 26.0 \\
\hline 22.00 & 4 & 2.0 \\
\hline 23.00 & 4 & 1.0 \\
\hline Total & 200 & 100.0 \\
\hline \multicolumn{3}{|l|}{ Semester } \\
\hline $5^{\text {th }}$ & 53 & 26.5 \\
\hline $6^{\text {th }}$ & 147 & 73.5 \\
\hline Total & 200 & 100.0 \\
\hline
\end{tabular}

Factor Analysis

The overall reliability of the questionnaire was found to be 0.933 . The KMO score is 0.889 , which shows that sample was adequate and internally consistent.

Table 1

Values of KMO and Bartlett's Test KMO and Bartlett's Test

\begin{tabular}{|c|c|c|}
\hline \multicolumn{2}{|c|}{ Kaiser-Meyer-Olkin Measure of Sampling Adequacy. } & .889 \\
\hline Bartlett's Test of Sphericity & $\begin{array}{l}\text { Approx. Chi-Square } \\
\text { df } \\
\text { Sig }\end{array}$ & $\begin{array}{l}3716.662 \\
630 \\
000\end{array}$ \\
\hline
\end{tabular}

Researchers executed a confirmatory factor analysis to check the strength of constructs mentioned in the conceptual framework. The constructs thus yielded confirmed the recommended criterion for selection, factor loadings for each item were <.3, and each item was correlated with at least one other item in the construct (Anderson, 2003; Fava \& Velicer, 1996). See Appendix A for further details. 


\section{Pearson Product Moment Correlation}

After confirming the constructs' reliability, the association among the research variables was determined by applying Product Moment Correlation. Results are described in the following table:

Table 2.

Pearson Product Moment Correlation

\begin{tabular}{|c|c|c|c|c|c|c|}
\hline & TPQ & PCK & TLE & AAD & SSD & SSC \\
\hline Authentic Pedagogy & 1 & $.727^{* * 2}$ & $.598^{* *}$ & $.576^{* *}$ & $.717^{* *}$ & $.725^{* *}$ \\
\hline Pedagogic Content Knowledge & & 1 & $.474^{* *}$ & $.684^{* *}$ & $.705^{* *}$ & $.721^{* *}$ \\
\hline $\begin{array}{l}\text { Teaching and learning } \\
\text { environment }\end{array}$ & & & 1 & $.417^{* *}$ & $.524^{* *}$ & $.593^{* * *}$ \\
\hline Affective Dimension & & & & 1 & $.726^{* *}$ & $.651^{* *}$ \\
\hline Support Dimension & & & & & 1 & $.758^{* *}$ \\
\hline Student Success & & & & & & 1 \\
\hline
\end{tabular}

The results show that the 'support dimension' of the construct teacher-student relationship (TSR) is most strongly and positively correlated with student success $(r=.758 ; p<.000)$. Similarly, authentic knowledge is strongly and positively correlated with student success $(r=.725 ; p<.000)$. Pedagogic content knowledge is also positively correlated with student success $(\mathrm{r}=.721 ; \mathrm{p}<.000)$. 'Affective dimension' of the construct teacher-student relationship (TSR) is moderately and positively correlated with student success $(\mathrm{r}=.651 ; \mathrm{p}<.000)$, whereas, teaching and learning environment is the least correlated with student success $(\mathrm{r}=.593 ; \mathrm{p}<.000)$.

\section{Multiple Linear Regression}

The positive association among various factors was confirmed; therefore, the researcher proceeded to determine how strongly student success is predicted by other constructs of epistemologicalpedagogical access using a stepwise method. Authentic pedagogy (teacher pedagogical content and teacher pedagogic quality), teaching and learning environment, both dimensions of student-teacher relationship (affective and support) were added as independent variables. Four models were generated, illustrating the predictive value of the support dimension of the student-teacher relationship, teacher pedagogical content, teaching and learning environment, and teacher's pedagogic quality. However, the 'affective dimension' was not found to be a significant predictor of student success. See Table 3 for the generated models.

Table 3.

Multiple Linear Regression (Student Success is Dependent Variable)

\begin{tabular}{clccc}
\hline No. & Model & $\beta$ & t-value & p-value \\
\hline 1 & (Constant) & & & .705 \\
& Support Dimension & .758 & 16.357 & .000 \\
& (Constant) & & -2.196 & .029 \\
& Support Dimension & .497 & 8.285 & .000 \\
& pedagogical content knowledge & .370 & 6.173 & .000 \\
3 & (Constant) & & -2.922 & .004 \\
& Support Dimension & .412 & 6.883 & .000 \\
& pedagogical content knowledge & .324 & 5.588 & .000 \\
& Teaching \& Learning Environment & .224 & 4.635 & .000 \\
& (Constant) & & -2.921 & .004 \\
& Support Dimension & .358 & 5.698 & .000 \\
& pedagogical content knowledge & .256 & 4.066 & .000 \\
& Teaching \& Learning Environment & .180 & 3.553 & .011 \\
\hline
\end{tabular}

The 1st model depicted in the table above evidenced that the support dimension of studentsteacher relationship most strongly and singularly explains $75 \%$ variance in student success $(\beta=.758$; $\mathrm{p}=.000$ ). The 2 nd Model verified that the support dimension of student-teacher relationship and pedagogical content knowledge collectively explain $86 \%$ variance in student success $(\beta=.497$; $\mathrm{p}=.000 ; \beta=.370 ; \mathrm{p}=.000)$.

The 3rd Model confirmed that the support dimension of student-teacher relationship, pedagogical content knowledge, and teaching and learning environment collectively explain 95\% variance in student success $(\beta=.417 ; p=.000 ; \beta=.324 ; p=.000 ; \beta=.224 ; p=.000)$. The last and fourth model of the study illustrated that the support dimension of student-teacher relationship, 
pedagogical content knowledge, teaching- learning environment and authentic pedagogy collectively explain 90\% variance in student success $(\beta=.358 ; \mathrm{p}=.000 ; \beta=.256 ; \mathrm{p}=.000 ; \beta=.180 ; \mathrm{p}=.000 ; \beta=$ $.175 ; \mathrm{p}=.000)$.

\section{Discussion}

According to the results, the support dimension of the student-teacher relationship was rendered the most critical factor by students for their success. A consistent rise in research on student-teacher interaction and relationships has been observed (Gerda \& Simon, 2014). It is ascertained that the frequency of interactions does not ensure the quality of the relationships; thus, the difference in interaction and relationship (Dobransky \& Frymier, 2004; Komarraju et al., 2010) can be attributed to the traditional culture of Pakistan, where rational attitude and assistance are expected from teachers, and emotional support is not a priority. It means that the combination of skills, abilities, and knowledge is needed to influence students toward success.

Though physical expansion has increased access to higher education institutes; however, access to knowledge is still limited, which blocks epistemological access to the provided places. It appears that the pedagogic content is not delivered by many teachers as expected by their students. Many pedagogues, psychologists, and epistemologists argue that uncertainties and risks characterize a transition from high modernity to late modernity, thus fails to provide epistemological access to knowledge as expected (Engestrom, 1991; Giddens, 1999; Archer, 2007). The question is how a different epistemological context demands a change in teachers' pedagogic practices to enable desired epistemological access for students (Lotz-Sisitka, 2009). Hackman (2005) advocated that university leadership plays a significant role in shaping teachers' efforts to manage the pedagogic content in useful ways for epistemological access. Hence it is advised that faculty approach these findings objectively seriously and bring improvement in their pedagogic content and delivery so that students might perceive it as authentic pedagogy, which helps them solve real-life problems of students.

\section{Conclusions}

The sub-factors of epistemological-pedagogical access (authentic pedagogy, pedagogical content knowledge, teaching-learning environment, affective, and support dimensions of student-teacher relationship) exert a positive interactive effect upon student success.

The support dimension of the student-teacher relationship, pedagogical content knowledge are the most dominant factors determining epistemological-pedagogical access to students at universities in Lahore. The teaching and learning environment are a moderate influencer, whereas affective dimension and authentic pedagogy influenced student success the least.

\section{Implications}

The study states implications for university faculty on how they can avoid misteaching, underteaching, and no-teaching on one hand (Lotz-Sisitka, 2009; Omar \& Chaudhary, 2019; Rosenberg, 2008) and on the other, promote student engagement by providing real-life practices. The expressed dissatisfaction of students with provided facilities at higher education institutions speaks of wasting of existing physical and intellectual resources (Arif et al., 2013, 2017), and acts as a barrier in creating student willingness for purposeful access. Management and teacher efforts shall provide a 'potentiating learning environment' (Claxton \& Carr, 2004) to stretch academic experiences into successful life-long learning experiences. Moreover, justification and truth connection reveals the fact that lack of resources provides no 'practical justification' for the misuse of accessible resources; instead, we need to have 'epistemic justification' - maximizing truth and minimizing falsity - for accurate perception of the higher education institutes in Pakistan (Cullison, 2012). So, to have epistemological access to higher education, we shall make teacher efforts and management efforts purposeful for customer satisfaction to translate students' academic experiences into meaningful opportunities in the practical world. Moreover, a sense of willingness to learn among students must be cultivated by inspiring them to be self-directed, enhancing self-competence to access the provided resources meaningfully.

Furthermore, teachers need to differentiate between contextualized and de-contextualized knowledge to decide what is to be taught at a certain level and then find appropriate ways to teach the required content (Lotz-Sisitka, 2009; Omar \& Chadhary, 2019). This contextual complexity needs to be dealt with care because an attempt to engage with contextual knowledge without structured and systematic approaches results in confusion and chaos, whereas to engage without contextual 
knowledge with structured and systematic approaches results in needless structural repetition (Morrow, 2007; Lotz-Sisitka, 2009). Similarly, teachers often limit their knowledge to what they have experienced, and they have researched and find the same context to make the concepts clear to the students, which would be re-contextualized to enable the teachers to think out of the box and relate knowledge to the context of the learners (Bernstein, 1990).

Along with this re-contextualization, the researchers need to adopt an open-ended notion of epistemological access by using an inter-disciplinary and trans-disciplinary approach to find solutions for the complex contexts of the postmodern world (Lotz-Sisitka, 2009). Finding network or hybrid spaces among varied disciplines would help to develop disciplinary structures in a better way. Similarly, structural knowledge is not always linear, and skills can be taught reflexively by engaging the learners more flexibly.

\section{References}

Aldrup, K., Klusmann, U., Lüdtke, O., Göllner, R., \& Trautwein, U. (2018). Student misbehavior and teacher well-being: Testing the mediating role of the teacher-student relationship. Learning and Instruction, 58, 126-136.

Alexander, R. (2008). Education for All, The Quality Imperative, and the Problem of Pedagogy. CREATE Pathways to Access. Research Monograph No. 20.

Alexander, R. J. (2015). Teaching and learning for all? The quality imperative revisited. International Journal of Educational Development, 40, 250-258.

Anderson, T. W. (2003). An introduction to multivariate statistical analysis (3rd ed.). John Wiley and Sons.

Arif, S., Ilyas, M. \& Hameed, A. (2013). Student Satisfaction with Services in Private Universities of Pakistan: The Impact of Leadership. Total Quality Management (TQM), 25(4), 399-416.

Arif, S., Ilyas, M., \& Hameed, A. (2017). Using structural equation modeling to construct student satisfaction models for private universities of Pakistan. Journal of Quality and Technology Management, 14(2), 39-53.

Asikainen, H., Blomster, J., \& Virtanen, V. (2018). From functioning communality to hostile behavior: students' and teachers' experiences of the teacher-student relationship in the academic community. Journal of Further and Higher Education, 42(5), 633-648.

Bagnall, R.G., \& Hodge, S. (2017). Using an Epistemological Perspective to Understand Competence-based Vocational and Professional Education. In M. Mulder (Eds.) Competence-based Vocational and Professional Education. Technical and Vocational Education and Training: Issues, Concerns and Prospects, Vol 23 (pp. 125-144). Springer

Becker, T. E., Atinc, G., Breaugh, J. A., Carlson, K. D., Edwards, J. R., \& Spector, P. E. (2016). Statistical control in correlational studies: 10 essential recommendations for organizational researchers. Journal of Organizational Behavior, 37(2), 157-167

Bergin, C., \& Bergin, D. (2009). Attachment in the classroom. Educational Psychology Review, 21(2), 141-170.

Bernstein, B. (1990). Class, Codes, and Control. 4. The structuring of pedagogical discourse.

Bernstein-Yamashiro, B., \& Noam, G. G. (Eds.). (2013). Teacher-Student Relationships: Toward Personalized Education: New Directions for Youth Development, Number 137 (Vol. 125). John Wiley \& Sons.

Biggs, J. (2014). Constructive alignment in university teaching. HERDSA Review of higher education, $1(1), 5-22$.

Bozalek, V., Ng' ambi, D., Wood, D., Herrington, J., Hardman, J., \& Amory, A. (2014). Activity theory, authentic learning, and emerging technologies: Towards a transformative higher education pedagogy. Routledge.

Burgoon, J. K., Stern, L. A., \& Dillman, L. (2007). Interpersonal adaptation: Dyadic interaction patterns. Cambridge University Press.

Calvo, R. A., Markauskaite, L., \& Trigwell, K. (2010). Factors affecting students' experiences and satisfaction about teaching quality in engineering. Australasian Journal of Engineering Education, 16(2), 139-148.

Clegg, S. (2011). Cultural capital and agency: Connecting critique and curriculum in higher education. British Journal of Sociology of Education, 32(1), 93-108. 
Creswell, J. W. (2005). Educational research: Planning, conducting, and evaluating quantitative and qualitative research (2nd ed.). Pearson Education.

Creswell, J. W., \& Creswell, J. D. (2017). Research design: Qualitative, quantitative, and mixed methods approaches. Sage.

Cydis, S. (2015). Authentic instruction and technology literacy. Journal of Learning Design, 8(1), 6878.

Devlin, M., \& O'Shea, H. (2012). Effective university teaching: Views of Australian university students from low socio-economic status backgrounds. Teaching in Higher Education, 17(4), 385-397.

Fantl, J. (2008). Knowing-How and knowing-that. Philosophy Compass, 3(3), 451-470.

Fataar, A. (2012). Pedagogical justice and student engagement in South African schooling: Working with the cultural capital of disadvantaged students. Perspectives in Education, 30(4), 52-75.

Fava, J. L., \& Velicer, W. F. (1996). The effects of under extraction in factor and component analysis. Educational and Psychological Measurement, 56, 907 - 929.

Gilbreath, J. N., \& Eastman, K. S. (2017, August). The Credible Hulk: smashing student expectations through instructor credibility. In National LOEX Library Instruction Conference (2016: Pittsburgh, PA).

Govinda, R., \& Bandyopadhyay, M. (2011). Overcoming Exclusion through Quality Schooling. Pathways to Access. Research Monograph No. 65.

Gürgil, F. (2018). The Effect of Authentic Learning Approach in Social Studies Teaching on the Academic Success. Universal Journal of Educational Research, 6(10), 2061-2068.

Hagenauer, G., Reitbauer, E., \& Hascher, T. (2013). "It's cool but challenging." The relevance of basic need fulfillment for students' school enjoyment and emotional experiences at the transition from primary to secondary education. Orbis Scholae, 7(2), 23-42.

Hagenauer, G., \& Volet, S. E. (2014a). Teacher-student relationship at university: an important yet under-researched field. Oxford Review of Education, 40(3), 370-388.

Hagenauer, G., \& Volet, S. (2014b). 'I don't think I could, you know, just teach without any emotion': Exploring the nature and origin of university teachers' emotions. Research Papers in Education, 29(2), 240-262.

Hagenauer, G., Hascher, T., \& Volet, S. E. (2015). Teacher emotions in the classroom: associations with students' engagement, classroom discipline, and the interpersonal teacher-student relationship. European Journal of Psychology of Education, 30(4), 385-403.

Haseloff, M. (2007). Students amid Pedagogic Change: Partners or Pawns. International Education Journal, 8(2), 81-91.

Joyce, J., Gitomer, D. H., \& Iaconangelo, C. J. (2018). Classroom assignments as measures of teaching quality. Learning and instruction, 54, 48-61.

Karpouza, E., \& Emvalotis, A. (2019). Exploring the teacher-student relationship in graduate education: a constructivist grounded theory. Teaching in Higher Education, 24(2), 121-140.

Kim, H.-J. (2017). Path analysis of faculty-student interaction, self-directed learning, and institutional commitment to impact on the academic achievement of the university students. Journal of Fisheries and Marine Sciences Education, 29(1), 40-50.

Leary, M. R., \& Baumeister, R. F. (2017). The need to belong: Desire for interpersonal attachments as a fundamental human motivation. In R. Zukauskiene (Ed). Interpersonal Development (pp. 57-89). Routledge.

Lotz-Sisitka, H. (2009). Epistemological access as an open question in education. Journal of Education, 46, 57-79.

Lundberg, C. A., \& Schreiner, L. A. (2004). Quality and frequency of faculty-student interaction as predictors of learning: An analysis by student race/ethnicity. Journal of College Student Development, 45(5), 549-565.

Magolda, M. B. B. (2014). Students' Epistemologies and Academic Experiences: implications for Pedagogy. College Student Development and Academic Life: Psychological, Intellectual, Social, and Moral Issues, 15(3), 117.

Mishra, P., \& Koehler, M. J. (2006). Technological pedagogical content knowledge: A framework for teacher knowledge. Teachers College Record, 108(6), 10-17 
Moll, L. C., \& González, N. (2004). Engaging life: A funds-of-knowledge approach to multicultural education. Handbook of research on multicultural education, 2, 699-715.

Morrow, W. (1994). Entitlement and achievement in education. Studies in Philosophy and Education, $13(1), 33-47$.

Morrow, W. (2007). Learning to teach in South Africa. HSRC Press.

Morrow, W. (2009). Bounds of democracy: Epistemological access in higher education. HSRC Press.

Motala, S., \& Carel, D. (2019). Educational Funding and Equity in South African Schools. In N. Spaull \& J. Jansen (Eds.) South African Schooling: The Enigma of Inequality. Policy Implications of Research in Education, (Vol 10, pp. 67-85). Springer.

Muller, J. (2014). Every picture tells a story: Epistemological access and knowledge. Education as Change, 18(2), 255-269.

Newmann, F. M., Marks, H. M., \& Gamoran, A. (1996). Authentic pedagogy and student performance. American Journal of Education, 104(4), 280-312.

Omar, I., \& Chaudhry, M. S. (2019). University Efforts for Quality to Ensure Epistemological Access. UMT Education Review, 2(1), 81-105.

Pendlebury, S. (2009). Meaningful access to basic education. South African Child Gauge, 2008/2009, 24-29.

Pennings, H. J., van Tartwijk, J., Wubbels, T., Claessens, L. C., van der Want, A. C., \& Brekelmans, M. (2014). Real-time teacher-student interactions: A dynamic systems approach. Teaching and Teacher Education, 37, 183-193.

Pennings, H. J., Brekelmans, M., Sadler, P., Claessens, L. C., van der Want, A. C., \& van Tartwijk, J. (2018). Interpersonal adaptation in teacher-student interaction. Learning and Instruction, 55, 41-57.

Ramseyer, F., \& Tschacher, W. (2016). Movement Coordination in Psychotherapy: Synchrony of Hand Movements is Associated with Session Outcome. Nonlinear Dynamics, Psychology, And Life Sciences, 20(2), 145-166.

Riley, P. (2009). An adult attachment perspective on the student-teacher relationship \& classroom management difficulties. Teaching and Teacher Education, 25(5), 626-635.

Riley, P. (2010). Attachment theory and the teacher-student relationship: A practical guide for teachers, teacher educators, and school leaders. Routledge.

Roorda, D. L., Koomen, H. M., Spilt, J. L., \& Oort, F. J. (2011). The influence of affective teacherstudent relationships on students' school engagement and achievement: A meta-analytic approach. Review of educational research, 81(4), 493-529.

Roorda, D. L., Jak, S., Zee, M., Oort, F. J., \& Koomen, H. M. (2017). Affective Teacher-Student Relationships and Students' Engagement and Achievement: A Meta-Analytic Update and Test of the Mediating Role of Engagement. School Psychology Review, 46(3), 239-261.

Ryle, G. (1945, January). Knowing how and knowing that: The presidential address. Proceedings of the Aristotelian Society (Vol. 46, pp. 1-16). Oxford University Press.

Samoff, J. (2001). Education for All" in Africa but education systems that serve a few well. Perspectives in Education, 19(1), 5-28.

Shulman, L. (1987). Knowledge and teaching: Foundations of the new reform. Harvard Educational Review, 57(1), 1-23.

Skourdoumbis, A. (2014). Teacher effectiveness: Making the difference to student achievement. British Journal of Educational Studies, 62(2), 111-126.

Sloan, A., \& Bowe, B. (2014). Phenomenology and hermeneutic phenomenology: The philosophy, the methodologies, and using hermeneutic phenomenology to investigate lecturers' experiences of curriculum design. Quality \& Quantity, 48(3), 1291-1303.

Snijders, I., Wijnia, L., Rikers, R. M. J. P., \& Loyens, S. M. M. (2020). Building bridges in higher education: Student-faculty relationship quality, student engagement, and student loyalty. International Journal of Educational Research, 100, 101538.

Spilt, J. L., Koomen, H. M., \& Thijs, J. T. (2011). Teacher wellbeing: The importance of teacherstudent relationships. Educational Psychology Review, 23(4), 457-477.

Winch, C. (2013). Curriculum design and epistemic ascent. Journal of Philosophy of Education, 47(1), 128-146. 
Yilmaz, K. (2013). Comparison of quantitative and qualitative research traditions: Epistemological, theoretical, and methodological differences. European Journal of Education, 48(2), 311-325.

Zepke, N., \& Leach, L. (2010). Beyond hard outcomes: 'Soft' outcomes and engagement as student success. Teaching in Higher Education, 15(6), 661-673. 